GEOGRAFICKÝ ČASOPIS / GEOGRAPHICAL JOURNAL 70 (2018) 4, 373-389

DOI: https://doi.org/10.31577/geogrcas.2018.70.4.20

\title{
TEMPORALITA CHUDOBY VO VYBRANÝCH OKRESOCH SLOVENSKA
}

\author{
Anton Michálek* \\ * Geografický ústav SAV, Štefánikova 49, 81473 Bratislava, geogami@savba.sk
}

\begin{abstract}
Temporality of poverty in selected districts of Slovakia
Due to the continuous growth of inequality, whether on the global or regional level, for the complex research of poverty, it is necessary to target its temporality. This article examines conceptual-methodological and empirical aspects of research of the temporality of poverty. The main objective of this article is, to set the temporality in the poverty districts of Slovakia, and based on this, to set the different types and identify chronically poverty districts. The following objective is to provide relevant theoretical bases and empirical findings on the relationship between the severity of poverty and its duration in Slovakia. To accomplish our main objective, we used period analysis and component analysis. To observe the relationship between these phenomena (the severity and duration of poverty), Spearman's correlation coefficient was used. The results of the analysis showed the differentiated character of poverty districts in Slovakia from the aspect of the duration of the poverty. The most widespread are the districts of chronic poverty, with the worst situation in the Kežmarok, Vranov nad Topl'ou and Rimavská Sobota districts. The results also confirmed our hypothesis of a significant correlation between the severity of poverty (depth) and the chronicity of poverty (length) in poverty districts in Slovakia.
\end{abstract}

Key words: poverty, temporality, chronic (permanent) poverty, deprivation, districts, spells approach, component analysis, districts of Slovakia

\section{ÚVOD}

Chudoba na Slovensku sa stala významným negatívnym sprievodným javom transformácie spoločnosti po roku 1989. Jej výrazný nárast v 90. rokoch minulého storočia bol výsledkom prudkých spoločensko-ekonomických zmien, dôsledkom kultúrneho a civilizačného procesu, ako aj množstva reforiem a d'alších faktorov. Významným sprievodným javom a aspektom zmien $\mathrm{v}$ spoločnosti bol rast nerovností, pričom výrazné sociálne a majetkové rozdiely medzi jednotlivými skupinami obyvatel'stva viedli a stále vedú k príjmovej polarizácii spoločnosti. Na jednej strane sa zvýraznili existenčné problémy niektorých početných kategórií obyvatel'stva, na strane druhej sa neúmerne rýchlo zvyšovalo a stále zvyšuje bohatstvo relatívne úzkej skupiny populácie. Z dôvodu neustáleho rastu nerovností možno očakávat' ich silnejúci vplyv na chudobu. Preto je potrebné $\mathrm{v}$ rámci komplexného výskumu chudoby v globálnej mierke, ale aj na Slovensku, zamerat' pozornost' na detailnú rekognoskáciu jej časových aspektov. $\mathrm{V}$ rámci takýchto, na trvanie a dynamiku chudoby zameraných výskumov je potrebné prioritne venovat' pozornost' sledovaniu temporality chudoby - skúmaniu jej krátkodobého, prechodného, dlhodobého alebo trvalého charakteru. Trvanie chudoby má významný priamy vzt’ah $\mathrm{k}$ úrovni, závažnosti, ale aj k d’alším významným atribútom chudoby, čo poukazuje a umocňuje relevantnost' jej skúmania. K výskumu temporality chudoby sa dá pristupovat' $\mathrm{z}$ rôznych aspektov. Pomerne vel'mi dobre sa dá pozorovat' a skúmat' z geografického pohl'adu (v priestorových analýzach) pri identifikovaní dlhodobo chudobných území, regiónov alebo lokalít. Zastúpenie časových typov chudoby v rôznych pries- 
torových jednotkách a ich charakter z aspektu trvania chudoby výrazne ovplyvňuje vývoj a možnosti ich rozvoja. Regióny s krátkodobou chudobou majú vo všeobecnosti väčšie možnosti a potenciál rozvoja a dokážu sa lepšie vyrovnat' s ekonomickými turbulenciami. Na druhej strane výskyt chronickej chudoby v niektorých regiónoch umocňuje ich problémovost'. Inými slovami, dlhodobo pretrvávajúca, resp. permanentná chudoba sa $\mathrm{v}$ niektorých regiónoch stáva t’ažko riešitel'ným problémom.

$\mathrm{V}$ príspevku sa pokúsime $\mathrm{v}$ kontexte $\mathrm{s}$ uvedenými poznámkami a poznatkami odpovedat' na dve konkrétne a z viacerých aspektov relevantné otázky. Prvou otázkou je, ako sa identifikované okresy chudoby (d’alej $\mathrm{OCH}$ ) na Slovensku odlišujú na základe dížky (trvania) chudoby a druhou, či existuje vzt’ah, resp. (ne)závislost' medzi sledovanými javmi (dížkou a závažnost'ou) chudoby, teda či dížka trvania chudoby ovplyvňuje jej závažnost'. Odpovede na tieto otázky sú predpokladom a východiskom pre dosiahnutie stanovených ciel'ov tejto štúdie, ktorá má dva ciele. Prvým ciel'om je zachytit' a zmerat' najvýznamnejší časový atribút chudoby, a to jej dížku (trvanie) v identifikovaných OCH. Na základe získaných výsledkov vykonat' časovú typológiu OCH a identifikovat' chronicky chudobné okresy. Druhým ciel'om je overenie hypotézy o vzt'ahu medzi závažnost'ou chudoby a jej chronickost’ou v podmienkach Slovenska. Vychádzame z predpokladu, že chronická chudoba je významným predikátorom (ukazovatel'om) jej závažnosti. Potvrdenie alebo vyvrátenie uvedenej hypotézy má využitie najmä v okresoch so závažnou a dlhodobou chudobou. Získané poznatky a ich úspešné aplikačné využitie by mohli viest' k zníženiu úrovne, resp. prerušeniu chronickej chudoby v postihnutých okresoch.

\section{SÚČASNÝ STAV A VÝZNAM VÝSKUMU TEMPORALITY CHUDOBY}

Od 90. rokov minulého storočia dochádza nielen k významným zmenám vo vymedzení a meraní chudoby, ale aj k rozšíreniu tém zameraných na skúmanie jej temporality. Táto skutočnost' z vel'kej časti súvisí s postupnou lepšou dostupnost'ou longitudinálnych, prierezových, resp. panelových dát o chudobe. Pre vedcov má lepšia dostupnost' dát vel'ký význam, pretože výskumy zamerané na trvanie a vývoj chudoby dokážu nielen identifikovat' pozitívne alebo negatívne smerovanie, ale aj predikovat' mnohé sociálne a demografické aspekty a správanie obyvatel'ov. Relevantnost' skúmania problematiky narastá v dôsledku dynamického vývoja a procesov v spoločnosti, rýchlych zmien, implementácie mnohých významných sociálnych a regionálnych politík v dôsledku integračných tendencií, ale aj pre možnú zranitel'nost' v prípade nepriaznivého vývoja. Sledovat' časovú dimenziu chudoby, zvlášt' v malých priestorových jednotkách, akými sú NUTS 4, resp. LAU 1 (okresy) alebo LAU 2 (lokality, resp. obce), nie je jednoduchou záležitost'ou. Dôvodom je najmä slabá rozpracovanost' konceptov a metodík a nestabilita porovnatel’ných priestorových jednotiek (napr. v dôsledku zmien administratívneho členenia územných jednotiek). Medzi hlavné ciele skúmania temporality chudoby z priestorového hl'adiska patrí najmä snaha identifikovat' chronicky chudobné regióny, poukázat' na najvýraznejšie zmeny a posuny, ktoré sa v regiónoch odohrávajú, na ich súvislost' so všeobecnými trendmi, a vytvorit' predpoklady a zázemie na sledovanie d'alších aspektov chudoby $\mathrm{v}$ priestore. Táto skutočnost' vychádza zo záujmu a potrieb pochopenia dôvodov dlhodobého trvania chudoby, priebehu schudobnenia, dynamiky a zmien v určitých ,kritických“ časových horizontoch. Časopriestorový aspekt chudoby má výrazný vplyv aj na nové pozície regiónov. Napriek preukázanej relevantnosti témy i lepšej dostupnosti longitudinálnych dát je 
v súčasnosti výskum temporality chudoby na rôznych priestorových úrovniach pomerne málo zastúpený. Zvlášt' absentujú témy týkajúce sa jej stability alebo zmien v najviac postihnutých oblastiach a regiónoch chudoby, ale aj témy zamerané na analýzu vplyvu dlhodobej chudoby na jej úroveň. Longitudinálna analýza precizuje chudobu v regiónoch, pretože čas jej trvania úzko súvisí s jej úrovňou a charakterom. Súčasne dokáže v regiónoch odhalit’ fluktuáciu chudoby okolo hranice rizika chudoby a identifikovat' tie regióny, v ktorých sa obyvatel'stvo nachádza v „hlbokej“' chudobe. Vie zachytit' dynamiku chudoby, a tak identifikovat' zmenu, teda zhoršenie alebo zlepšenie situácie a tým vlastne upozornit' na negatívny alebo pozitívny vývoj regiónov. Prispieva tiež $\mathrm{k}$ pochopeniu determinantov chudoby, lebo umožňuje z časového hl'adiska analyzovat' skutočnosti stojace za vývojom hodnôt agregovaných ukazovatel'ov (Jenkins 2011). Umožňuje tiež zistit', či pokles počtu chudobných regiónov je výsledkom toho, že sa do chudoby prepadá menej regiónov, alebo toho, že sa z nej viac vymaňuje. Na základe doterajších poznatkov uvádzame pät' najvýznamnejších dôvodov poukazujúcich na relevantnost' problematiky a jej skúmania.

Po prvé, rozsah problému a jeho spoločensko-politické dôsledky sú vel'mi významné. K dispozícii je presvedčivé množstvo dôkazov, ktoré ukazujú, že časové analýzy chudoby môžu vysvetlit', prečo chudoba pretrváva v určitých regiónoch, prečo sa u obyvatel'ov v týchto regiónoch dedí z generácie na generáciu, prečo je t’ažké uniknút' z ,priestorovej“ pasce chudoby. Po druhé, je pravdepodobné, že výskum temporality, najmä vzhl'adom na chronickost' chudoby, do značnej miery odkrýva a charakterizuje kumulatívne nevýhody okresov: nízke výnosy všetkých foriem investícií, slabú integráciu, spoločenské a politické vylúčenie, nedostatočný prístup $\mathrm{k}$ verejným službám a d’alšie. Identifikácia chronickosti chudoby zároveň odkrýva dôsledky uvedených, ale aj d'alších kumulovaných nevýhod (ako napr. nízka úroveň príjmov a miezd, vysoká sociálna odkázanost', nízka životná úroveň a pod.). Po tretie, poukazuje na obmedzené možnosti l'udí, ktorí dlhodobo žijú v pasci chudoby, zvlášt' výrazne znižuje možnosti ich úniku z chudoby. To znamená, že aj ked' má jedinec podnikatel'ské zručnosti, kapitálové investície a vôl'u investovat' do podnikania, návratnost' investícií je nižšia ako v bohatších regiónoch, resp. v regiónoch s výskytom dočasnej alebo krátkodobej chudoby. Chronická chudoba znižuje úspešnost' podnikania a rozširuje svoj zhubný vplyv na investície (rizikovost', nižší zisk, dlhšia návratnost', ...) a l'udský kapitál (absencia uplatnenia vzdelania, zručností a kvalifikácie, zvyšuje sociálnu izoláciu, ...). Po štvrté, napriek tomu, že svet zažíva hospodársky rast (krátko prerušený v období krízy) a eviduje pokles počtu chudobných, ukazuje sa, že stále existujú krajiny a regióny chronickej chudoby, pre ktoré sú charakteristické jej najt’ažšie formy. Extrémna chronická chudoba vyskytujúca sa v niektorých krajinách a regiónoch ešte viac znižuje ich už aj tak nízky sociálno-ekonomický potenciál, obmedzuje možnosti rozvoja a spôsobuje množstvo d'alších problémov. Po piate, sú to čisto pragmatické dôvody súvisiace so signifikantnou skupinou chudobných l'udí, ktorí znižujú úroveň spotreby, pretože vyžadujú málo tovarov a služieb. Dĺžka (trvanie) chudoby v regiónoch a lokalitách výrazne negatívne ovplyvňuje všetky oblasti kvality života ich obyvatel'ov, pričom táto skutočnost' je v pozornosti rozvojových politík a debát a je čoraz viac akceptovaná v sociálnej, ale aj v regionálnej a lokálnej politike.

Z uvedeného je zrejmé, že poznatky o temporalite chudoby v regiónoch chudoby získané pomocou longitudinálnych analýz sú základným predpokladom a východiskom pri hl'adaní riešení a programov jej postupného znižovania, prípadne 
úplného odstránenia. V dôsledku spomínaných skutočností vzniká aj táto štúdia, ktorá chce aspoň čiastočne vyplnit’ medzeru chýbajúcich časových výskumov chudoby a jej rôznych aspektov s dôrazom na aspekt jej trvania. Príspevok sčasti predstavuje všeobecný konceptuálny návod a jedno z množstva riešení, ako možno analyzovat' najvýznamnejšie časové charakteristiky chudoby a ich vplyv na úroveň chudoby vo vybraných priestorových jednotkách. Predložené koncepty i metodické postupy využité pri vykonanej časovej typológii regiónov chudoby, alebo určení miery závislosti, môžu byt' využité aj v iných krajinách, najmä v krajinách s porovnatel'nou sociálno-ekonomickou situáciou a vývojom (napr. v krajinách strednej a východnej Európy).

\section{ČASOVÁ KLASIFIKÁCIA A KATEGÓRIE CHUDOBY}

Štúdium temporality chudoby sa zameriava hlavne na trvanie a analýzu zmien stavu chudoby - jej (ne)stabilitu v čase. Ciel'om výskumu je posúdit' dĺžku a zmeny v chudobe analýzou dížky jej trvania. Podl'a uvedeného kritéria (dížky trvania chudoby) možno chudobných zaradit' do troch agregovaných kategórií (AK), ktoré zahŕňajú pät' špecifických kategórií (vid' obr. 1). Do prvej kategórie zarad'ujeme chronicky chudobných, ktorých charakterizuje vysoká úroveň chudoby (vždy vyššia ako definovaná hranica chudoby na obrázku označená skratkou HDCH) v celom sledovanom období. Do tejto kategórie patria aj dlhodobo chudobní vyznačujúci sa „obvykle“ (nie však v každom období) vyššou úrovňou chudoby. Druhú kategóriu tvoria prechodne chudobní, ktorí sú opakovane chudobní. Charakterizuje ich „kolísavá“ chudoba (chudobní len v niektorých obdobiach), pričom úroveň ich chudoby osciluje okolo hranice chudoby. Do tejto kategórie patria aj občas (príležitostne) chudobní, ktorí zažili aspoň jedno obdobie v chudobe, aj ked' úroveň ich chudoby sa väčšinu času pohybuje nad hranicou chudoby. A konečne tretiu kategóriu tvoria l'udia, ktorí počas svojho života nikdy nezažili chudobu.

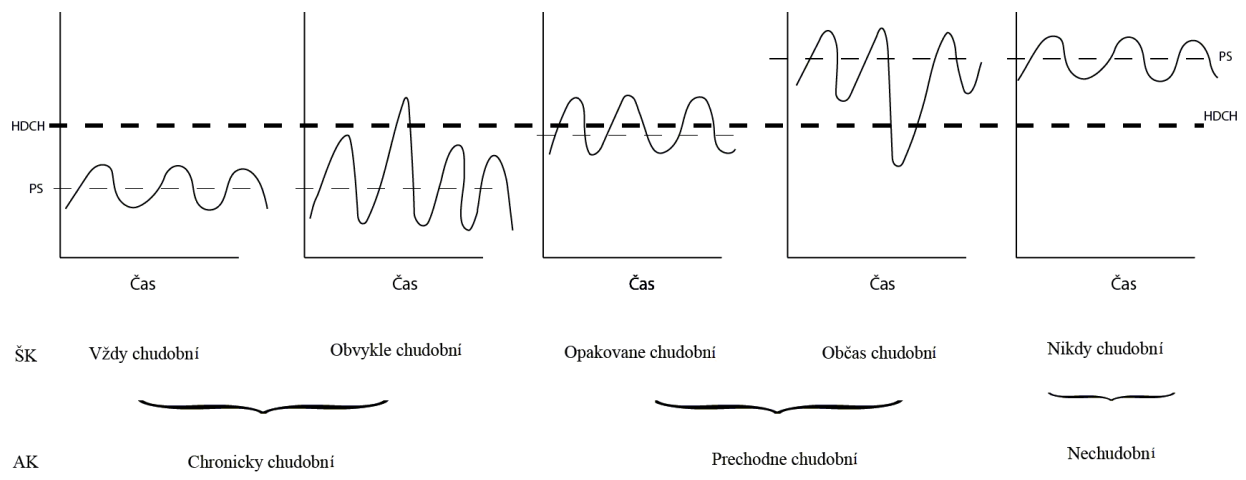

Obr. 1. Časová klasifikácia chudoby a kategórie chudoby

HDCH - hranica deprivačnej chudoby, PS - priemerné skóre, ŠK -špecifická kategória, AK - agregovaná kategória

Zdroj: Spracované autorom podl'a Jalan a Ravallion (2000).

Medzi uvedenými špecifickými kategóriami chudobných existuje pohyb, resp. presun, ktorý je až na malé výnimky významnejší len medzi susednými kategóriami. „Vzostupné“" pohyby charakterizujú tých chudobných, ktorí si zväčša krátkodo- 
bo, pod vplyvom rôznych pozitívnych, či už individuálnych (napr. v dôsledku získania práce, lepšie platenej práce, ...) alebo spoločenských príčin (ekonomický rast a hospodársky rozvoj, ...) ,polepšia“ a na čas sa presunú do inej kategórie chudobných (napr. chronicky chudobní prejdú do kategórie obvykle alebo opakovane chudobní). Naopak, tzv. „zostupné“ pohyby charakterizuje prechod do horšej kategórie chudobných, napr. ak sa l'udia prechodne chudobní presunú do kategórie dlhodobo chudobní, v extrémnych prípadoch až do kategórie chronicky chudobní. Takéto výrazne negatívne presuny sa odohrávajú zväčša v nepriaznivých obdobiach, ako napr. v období kríz, ekonomického poklesu, v dôsledku osobných zlyhaní, nepriaznivých individuálnych životných situácií (strata zamestnania, zhoršenie zdravotného stavu a iné), ako aj v dôsledku zmien životného cyklu (založenie rodiny, zaobstaranie bývania, odchod do dôchodku a iné).

Mobilitu medzi jednotlivými kategóriami vel'mi dobre vystihuje Gordonov model dynamiky chudoby (Gordon et al. 2000) zachytený na obr. 2. Model zachytáva mobilitu medzi štyrmi uvedenými základnými kategóriami populácií, pričom sústred'uje pozornost' na pohyb chudobných v obidvoch smeroch, ktorý je vyjadrený šípkami. Tieto ukazujú na pohyb vedúci bud' k zlepšeniu (šípka vo štvrtom kvadrante) alebo k zhoršeniu (šípka v druhom kvadrante) ich situácie v čase. Môžeme vidiet', že ak sa u chudobných ich príjem dostatočne zvýši, môže sa čast' z nich presunút' do pravej časti (štvrtý kvadrant) a neskôr, ak sa zvýšia aj ich výdavky a spotreba, prestávajú byt' chudobní (tretí kvadrant). U chudobných môžu nastat' ešte dve d'alšie situácie. Ked' krátkodobé zvýšenie príjmu zlepší ich životnú úroveň a čast' z nich sa presunie do kategórií nebohatých, resp. nechudobných (na grafe sa nachádzajú v priestore bledého obdlížnika prekrývajúceho čast' plochy troch kvadrantov okrem prvého). Avšak vel'ká čast' chudobných, aj ked' sa pokúšali udržat' si dosiahnutú životnú úroveň, sa vel'mi rýchlo prepadla do kategórie označenej ako zranitel'ní (ohrození). Táto skupina zranitel'ných sa napriek snahe udržat' si životnú úroveň v mnohých prípadoch po určitom čase stáva opät’ chudobná, teda padá do kategórie chudobných (na grafe prvý kvadrant vl'avo dole).

Ďalšou pridanou hodnotou tohto cenného a prehl'adného modelu je, že v rámci kategórií chudobných definuje najchudobnejších, tvoriacich jadro chudobných, a v rámci kategórie „nie chudobni““ - nadpriemerne bohatých. Široké spektrum informácií, ktoré model poskytuje, nám zároveň umožňuje zachytit’ a vyčlenit’ základné kategórie populácií charakterizované podl'a príjmu a životnej úrovne. Na základe obr. 2 môžeme vyčlenit’ štyri hlavné kategórie populácií:

- chudobní, ktorá zahŕňa i podkategóriu ,jadro chudobných“"1, l'udí trpiacich „komplexnou“" a hlbokou chudobou (sú nielen príjmovo chudobní, ale aj materiálne znevýhodnení a cítia sa aj subjektívne chudobní);

- zranitel'ní (nechudobní, resp. nebohatí) ${ }^{2}$ predstavujú populáciu nachádzajúcu sa tesne nad prahom životnej úrovne alebo v jeho blízkosti, resp. na hranici chudoby. Táto kategória je vel’mi "citlivá" aj na najmenšie ekonomické zmeny. V prípade nepriaznivého ekonomického vývoja alebo iných negatívnych okolností sa tieto

\footnotetext{
${ }^{1}$ Táto kategória tvorí vlastne ,jadro“ chudobných a sú pre ňu typické najt’ažšie formy chudoby, pričom sa súčasne vyznačujú najväčšou híbkou chudoby.

${ }^{2}$ V zahraničnej literatúre je táto kategória niekedy označovaná ako „breadline“ chudobní, teda „chudobní na/nad hranicou chudoby. Väčšina obyvatel'ov patriacich do tejto kategórie skutočne žije na hranici chudoby alebo tesne nad ňou a tým je vylúčená $\mathrm{z}$ niektorých sociálnych dávok a $\mathrm{z}$ účasti na získaných ekonomických výsledkoch a pôžitkoch spoločnosti.
} 
vel'mi rýchlo prejavia na zhoršení jej finančnej situácie a u časti tejto populácie aj pádom do kategórie chudobných;

- bohatnúci, ktorých príjem sa zvyšuje rýchlejšie ako životná úroveň, avšak stále nie sú dostatočne bohatí na to, aby odolali rôznym nepriaznivým, najmä ekonomickým alebo finančným okolnostiam a znova neprepadli sitom chudoby;

- „nie chudobní“, vlastnia určitý majetok a majú aj obvykle väčší príjem ako je priemer v spoločnosti. Do tejto kategórie Gordon et al. (2000) zaradili aj nadpriemerne bohatých s vel'mi vysokou životnou úrovňou a vysoko nadpriemernými príjmami.

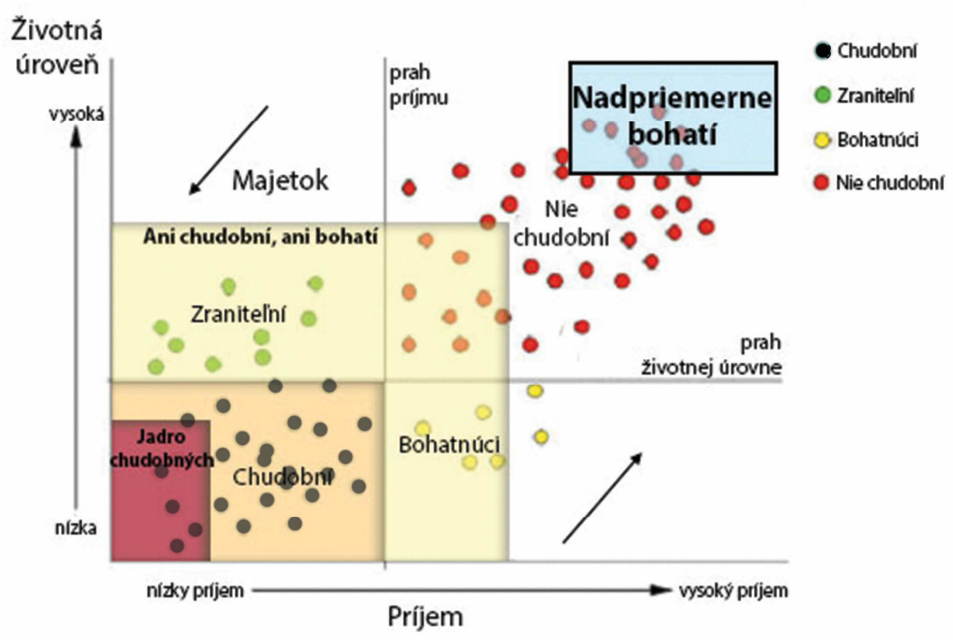

Obr. 2. Model dynamiky chudoby podla D. Gordona

Zdroj: Prevzaté z Dorlinga a Pritcharda (2010), originál Gordon, D. et al. (2000), upravené autorom.

Uvedené klasifikácie chudoby založené na dížke trvania chudoby a mobilite chudobných, vel'mi úzko súvisia s d'alšími charakteristikami, a to najmä s multidimenzionalitou, vážnost'ou (t'aživost'ou) chudoby a znakmi jej priestorovej dimenzie (marginalizáciou a exklúziou populácií, izolovanost'ou území, ich (nielen) geografickou polohou, ale aj odl'ahlost'ou a vzdialenost'ou od ekonomických centier, regiónov a rozvinutých území). $Z$ tohto dôvodu sa $\mathrm{v}$ nasledujúcej časti príspevku venujeme stručnej prezentácii chronickej (permanentnej) chudoby, ktorá je previazaná s najt’ažšími formami chudoby. Identifikácia chronicky chudobných regiónov je jedným z prioritných ciel’ov tejto štúdie.

\section{CHRONICKÁ (PERMANENTNÁ) CHUDOBA}

Chronická chudoba má celý rad termínov, ktoré indikujú, že ide o najzávažnejší typ chudoby. Často je označovaná aj ako chudoba extrémna (extreme poverty), permanentná (permanent poverty), niekedy tiež ako radikálna (ultra poor), jadrová (hardcore), chudoba ako núdza, bieda alebo „na mizine“ (destitute). Za chronickú chudobu možno považovat' chudobu pretrvávajúcu niekol'ko rokov, alebo aj celý život, ktorá je často prenášaná medzigeneračne. Takáto je definícia chronickej chu- 
doby uvedená v Správe o chronickej chudobe (Chronic poverty advisory network 2014). Hoci determinujúcim znakom chronickej chudoby je dížka jej trvania, má aj d'alšie charakteristické atribúty. Podl'a autorov Hulme et al. (2001) chronickú chudobu charakterizujú tri kl'účové znaky - dlhodobost'/dlhotrvácnost' (long duration), mnohorozmernost' (multi-dimensionality) a závažnost' (severity), ktoré sú graficky zachytené na obr. 3.

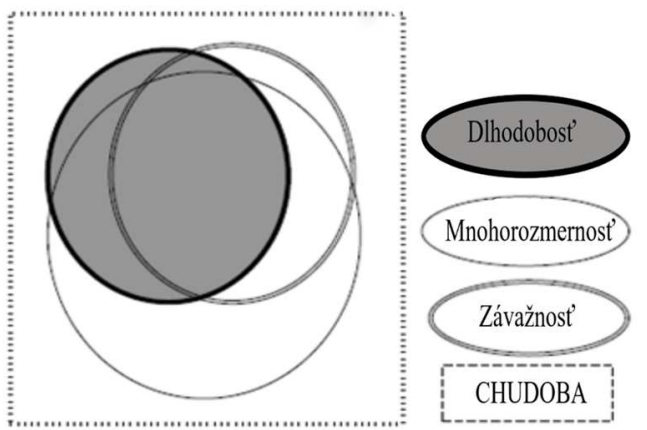

Obr. 3. Kl'účové (pretínajúce sa) znaky (charakteristiky) chronickej chudoby Zdroj: Hulme et al. (2001).

Britský ústav pre medzinárodný rozvoj (UK Department for International Development 2013) rozširuje skupinu kl'účových znakov chronickej chudoby (d'alej $\mathrm{CHCH}$ ) o priestor a uvádza štyri kl'účové vlastnosti (charakteristiky). Sú to:

1. Dížka (obdobie) trvania chudoby, ktorá je často označovaná ako determinujúca vlastnost' (charakteristika) chronickej chudoby. Akokol'vek t’ažká a multidimenzionálna je chudoba, ak netrvá dlhší čas, nie je chronickou, ale skôr prechodnou chudobou. Niektorí vedci sa domnievajú, že za CHCH možno považovat' chudobu, ktorá trvá nepretržite počas piatich rokov (Chronic poverty research centre 2004). Chronická chudoba môže mat' aj kratšie časové rámce (v jednotlivých ročných obdobiach) a samozrejme aj dlhšie (spojené so životnými cyklami). Dížka, resp. trvanie chudoby je tak klúčovým bodom $\mathrm{CHCH}$, pričom platí, že čím je toto obdobie dlhšie, tým viac vedie k strate majetku, ohrozeniu živobytia, strate zdravia a sociálnych väzieb. V neposlednom rade je dôležité si uvedomit', že chronická chudoba je často prenášaná naprieč generáciami a ohrozuje ich mobilitu na vertikálnej i horizontálnej osi, teda priamo ich budúcnost'.

2. Mnohorozmernost', ktorá je v súčasnosti vo všeobecnosti akceptovaná ako základný atribút chudoby, sa okrem nedostatku príjmov prejavuje širokým spektrom deprivácií (fyzické, ekonomické, sociálne, kultúrne atd’.). V súvislosti s chronickou chudobu možno konštatovat', že kumulácia deprivácií priamoúmerne zvyšuje chronickost' chudoby. Za najvýznamnejšie príčiny $\mathrm{CHCH}$ sú považované ekonomické podmienky a deprivácie, ktoré v značnej miere vytvárajú a formujú pasce chudoby (Carter a Barrett 2006 a Barrett a Carter 2013).

3. Závažnost' chudoby je tret'ou kl'účovou vlastnost'ou $\mathrm{CHCH}$, ktorá je vyjadrená medzerou chudoby, teda vzdialenost'ou chudoby od hranice chudoby. Pochopenie závažnosti chudoby je vo vzt’ahu $\mathrm{k}$ chronickosti chudoby dôležitou podmienkou, pretože umožňuje pohl'ad do stratégií a kompromisov chudobných (napr. 
zrieknutie sa zdravotného ošetrenia s ciel'om uspokojenia potrieb, napr. spotreba potravín pre domácnost'), postojov a vzt'ahov (averzia a apatia k spoločnosti), správania a preferencií (napr. priorita uspokojenie okamžitých potrieb obmedzuje možnosti týkajúce sa budúcich potrieb alebo ich odkladanie).

4. Odl'ahlost', resp. vel'ká vzdialenost' od politických, hospodárskych a iných významných centier a území. Chronická chudoba má tendenciu mat' vlastné priestorové charakteristiky, čo ukazuje na vysoký stupeň kovariantných rizík a kombinovaných súhrnných nevýhod. Chudobu môže "spustit"، alebo výrazne zhoršit' región alebo lokalita bývania. Dôležitou skutočnost'ou je, že oblasti s vyššou koncentráciou chudobných l'udí sa vyznačujú vyššou pravdepodobnostou koncentrácie chronickej chudoby. Fyzická (geografická) odl'ahlost' regiónov je často sprevádzaná politickou a ekonomickou odl'ahlost'ou, ktoré znižujú ich zapojenie do rozhodovacích procesov a možnosti ekonomickej aktivity obyvatel'ov. Tým zvyšujú riziko celkovej zranitel'nosti a chronickej chudoby. Odl'ahlost' je dôležitým faktorom a výrazne prispieva ku chronickej chudobe mnohých regiónov a lokalít a môže viest' k vzniku, zotrvaniu a rozšíreniu tzv. priestorových pascí chudoby (spatial poverty traps). Ako konštatujú Bird et al. (2010), podstatným znakom chronickej chudoby je jej silná priestorová koncentrácia, v značnej miere určujúca charakter chudobných regiónov.

Procesy, ktoré sú základom chronickej chudoby, sú komplexné a dynamické. Aj $\mathrm{z}$ tohto dôvodu uchopenie a pochopenie chronickej chudoby vyžaduje interdisciplinárnu spoluprácu. Táto kooperácia je zvlášt’ potrebná v konceptuálnej a metodologickej oblasti. Je nevyhnutné vypracovat' efektívnu kombináciu kvantitatívnych a kvalitatívnych metód, ktoré by dokázali postihnút' všetky relevantné aspekty najt’ažších foriem chudoby spojených s jej trvaním.

\section{NOSITELIA A INDIKÁTORY CHRONICKEJ CHUDOBY}

Chronická chudoba ovplyvňuje l’udí v rôznych situáciách. Chronicky chudobní sú l'udia, ktorí bežne zažívajú niekol'ko foriem znevýhodnení, deprivácií a diskriminácií v rovnakom čase a dlhodobo. L’udia v chronickej chudobe majú najmenší prospech z ekonomického rastu a vývoja. Chronicky chudobní zostávajú chudobní počas dlhšieho obdobia, alebo aj celý svoj život, a až na malé výnimky odovzdávajú chudobu aj svojim det'om. Oni a ich deti budú aj v budúcnosti tvorit' väčšinu z chudobných l'udí vo všetkých častiach a krajinách sveta. Hoci existuje chronická chudoba vo všetkých regiónoch, príčiny, podmienky, úroveň ich chudoby, životné situácie a d’alšie aspekty $\mathrm{CHCH}$ sú značne diferencované. Chronicky chudobní nie sú homogénnou skupinou. Rozdielne skupiny chronicky chudobných sa líšia od krajiny ku krajine, od regiónu $\mathrm{k}$ regiónu, od domácnosti k domácnosti, od osoby $\mathrm{k}$ osobe $-\mathrm{v}$ závislosti od prevažujúcich faktorov a príčin spojených $\mathrm{s}$ chudobou a spôsobujúcich chronickú chudobu. Rozdielne kombinácie štrukturálnych faktorov (práce a trhov, etnicity, pôvodu, rasy, pohlavia, náboženstva, sociálnych tried, zdravotného postihnutia a geografickej polohy), faktorov životného cyklu, zloženia a vel'kosti domácností, idiosynkretických (prírodná katastrofa, zdravotné postihnutie, lúpež a iné) a d’alších faktorov vytvárajú a udržiavajú chudobu. Uvedené, ale aj d'alšie faktory nám pomáhajú rozpoznat' vel'mi odlišné situácie a l'udí trpiacich chronickou chudobou, ako aj rôzne procesy, ktoré ich udržiavajú v stave chronickej chudoby. Je dôležité si uvedomit', že rozdiely v sebe skrývajú rôzne alternatívy $\mathrm{CHCH}$, ktorá je značne regionálne diferencovaná. Chronická chudoba a jej výskyt 
v jednotlivých regiónoch je výsledkom širokého spektra diferencovaných príčin a podmienok. Priestorové rozmiestnenie chronickej chudoby má svoje zákonitosti, príčiny a opodstatnenie. Napriek spoločným znakom je rozmiestnenie chronickej chudoby (jej koncentrácia) výrazne determinované geografickou polohou a ekonomickou vyspelost'ou krajiny. V tranzitívnych krajinách je výskyt chronickej chudoby spojený s viacpočetnou depriváciou, ktorá vytvára „,priestorové pasce“ chudoby. Neistoty trhovej ekonomiky najviac zasahujú odl'ahlé, ekonomicky alebo inak znevýhodnené a zaostávajúce regióny, ktoré sa nedokázali adaptovat' na politickoekonomické zmeny, čím sa ešte viac prehíbilo ich zaostávanie. Práve takéto regióny sa vyznačujú koncentráciou a zvýšeným výskytom obyvatel'stva v chronickej chudobe. Zväčša ide o okresy vzdialené od centier ekonomického a politického záujmu, s nízkym potenciálom pre rozvoj, slabou integráciou, t’ažkou dostupnost’ou z hl'adiska dopravných komunikácií, slabou infraštruktúrou, s nízkou úrovňou väzieb a kontaktov s rozvinutými regiónmi. Uvedené a d'alšie nevýhody sa $\mathrm{v}$ nich prekrývajú, navzájom posilňujú a kumulujú, čo spôsobuje nárast ich problémov a okrem iného aj predlžovanie a prehlbovanie chudoby ich obyvatel'ov. Negatívne dôsledky $\mathrm{CHCH}$ sa stali východiskom pre vytvorenie indikátorov $\mathrm{CHCH}$, ktoré sme sa pokúsili zosystematizovat'. Vytvorili sme sedem oblastí, ktorých indikátory sú spojené a výrazne poukazujú na $\mathrm{CHCH}$. Ide o indikátory z oblasti telesnej (fyzickej) nepohody (rôzne formy telesného postihnutia, chronicky zlý zdravotný stav, choroba v terminálnom štádiu, predčasné úmrtie ,živitel’a rodiny“), materiálneho nedostatku (vel'mi nízka úroveň celkových príjmov a vel'mi nízka úroveň spotreby), duševného vývoja a duševného zdravia (duševné zdravotné problémy, nízka úroveň l'udského kapitálu, vzdelania, vedomostí a zručností). Takisto sem patria indikátory pracovných možností a podmienok (nízka úroveň miezd, sekundárny trh práce, nelegálna a neistá práca, práca v zlých pracovných, najmä zdravotných podmienkach - úrazy a pl'úcne ochorenie), bezpečnosti a zabezpečenia (územia a regióny častých násilných konfliktov, zvýšená úroveň fyzickej neistoty spojená s nízkou úrovňou bezpečnosti, nedostatočný prístup k sociálnemu zabezpečeniu), sociálnych vzt’ahov (nízka úroveň sociálneho kapitálu, sociálnych sietí, slabá úroveň sociálnych vzt’ahov a väzieb, sociálna exklúzia a izolácia) a indikátory vplyvu, moci a prestíže (slabý, resp. žiadny vplyv a moc, nedostatok práv, neschopnost' ich využitia). Pri uvedenej systematizácii indikátorov $\mathrm{CHCH}$ sme vychádzali z práce autorov Hulme a McKay (2005), ktorí uvádzajú v súvislosti s konceptualizáciou chudoby dva významné argumenty. Prvým argumentom je potreba interdisciplinárneho prístupu a doplnenie indikátorov $\mathrm{CHCH}$ o „neekonomické“ charakteristiky. Druhým je potreba hl'adat' spôsoby, ako zabezpečit', aby chronická chudoba nebola analyzovaná cez príliš úzky objektív. Zoznam zachytáva najvšeobecnejšiu a pomerne širokú skupinu indikátorov platných pre všetky krajiny, avšak ich váha je diferencovaná $\mathrm{v}$ závislosti od podmienok jednotlivých krajín a regiónov. V tomto kontexte je zrejmá potreba tvorby špecifických indikátorov platných, ovplyvňujúcich a charakterizujúcich $\mathrm{CHCH}$ v jednotlivých krajinách.

\section{KONCEPTUALIZÁCIA VÝCHODÍSK PRE TYPIZÁCIU REGIÓNOV CHUDOBY Z ASPEKTU ČASU}

Z uvedeného je zrejmé, že z priestorového pohl'adu je chudoba dynamickým javom, ktorý prechádza vývojom a rôznymi zmenami. Dynamika chudoby sa môže týkat' nielen zmien jej úrovne, híbky, trvania, znakov, charakteru, ale i zmien jej priestorového výskytu. Regióny chudoby môžu byt' kategorizované podl'a množ- 
stva kritérií, a teda aj časového kritéria trvania chudoby. Podobne ako pri meraní chudoby v jednom časovom momente, vstupuje do analýzy vel'a faktorov, ktoré sú navyše doplňané dimenziou času. Muffels et al. (2000) dávajú do pozornosti štyri dimenzie dynamicky chápanej chudoby regiónu: dížku pozorovaného obdobia, dľžku trvania chudoby, rozsah striedavých období chudoby a nestálost' - (ne)stabilitu chudoby v čase. Pre každú z uvedených štyroch dimenzií existujú odlišné ukazovatele, ktoré umožňujú regionálne porovnanie. Tieto štyri dimenzie spolu určujú profil regiónov chudoby na časovej osi. V súvislosti s koncentráciou nositel'ov chudoby a jej trvaním možno regióny klasifikovat' ako regióny $\mathrm{v}$ stave trvalej chudoby, regióny v stave dlhodobej chudoby, regióny v stave dočasnej (prechodnej) chudoby, opakovane chudobné regióny (cyklicky, striedavo), regióny v stave krátkodobej chudoby a regióny bohaté, ktoré neboli nikdy chudobné. Doposial' neexistuje všeobecná zhoda, aká by mala byt' časová hranica (obdobie trvania chudoby) na určenie jednotlivých časových typov regiónov chudoby, resp. na identifikáciu $\mathrm{CHCH}$ regiónov. Vol'ba počtu rokov, ktoré slúžia ako klasifikačné kritérium medzi jednotlivými profilmi, je arbitrárna. Za najnižšiu hranicu napr. pre trvalú chudobu $(\mathrm{CHCH})$ možno v súčasnosti považovat' hranicu $3-5$ rokov, pričom väčšina odborníkov skôr uprednostňuje dlhšie časové obdobie. Chronicky chudobné regióny sa zväčša definujú a identifikujú podl'a podielu chronicky chudobných, ktorí zostávajú chudobní počas dlhšieho obdobia, alebo aj celý svoj život (Shepherd a Scott 2011). Stanovenie limitu (trvania chudoby) závisí od vel'kého množstva faktorov a v značnej miere je podmienené aj geograficky. V ekonomicky vyspelých krajinách časová hranica $\mathrm{CHCH}$ regiónov klesá v súvislosti s dynamickým vývojom a množstvom programov, opatrení, politík, ale aj finančných zdrojov smerovaných do chudobných regiónov. V niektorých krajinách sa za $\mathrm{CHCH}$ považujú regióny, v ktorých obyvatel'stvo trpí $\mathrm{CHCH}$ viac ako tri roky.

Diferencovaná úroveň chronicky chudobných, resp. ich vysoká koncentrácia v niektorých regiónoch je významným indikátorom ich nepriaznivej situácie a významným faktorom ich dlhodobého zaostávania. Analýzy chudoby v regiónoch $\mathrm{z}$ dlhšieho časového obdobia sú dôležité aj z aspektu zostavenia ich detailnejších profilov. Súčasne umožňujú sledovanie vývojových trendov a zmien v regiónoch, ako aj identifikáciu rizikových období. Z uvedeného možno predpokladat, že dížka pozorovania (počet rokov, počas ktorých sa sleduje chudoba v regióne) ovplyvňuje charakter, priebeh i samotný výskyt pretrvávajúcej chudoby. Sledovanie regiónov v dlhšom časovom období môže priniest' detailnejšie a kvalitnejšie výsledky než výskum kratších období.

Výskum chronickej chudoby a časových typov chudoby $\mathrm{v}$ regiónoch prináša množstvo d'alších otázok. Sú to napr. otázky súvisiace s možnost'ou ich kompenzácie v čase (napr. či obdobia, v ktorých je región v chudobe, môžu byt' vykompenzované obdobiami, v ktorých sa v chudobe nenachádza), s identifikáciou dlhodobej chudoby (napr. či možno každému obdobiu chudoby priradit' rovnakú váhu), analýzou vzt'ahu medzi závažnost'ou chudoby a jej chronickost'ou (napr. do akej miery je závažnost' chudoby predikátorom chronickej chudoby a naopak), alebo otázkami súvisiacimi s rozdielmi medzigeneračnej chudoby a medzigeneračného prenosu chudoby $\mathrm{v}$ regiónoch. Vidíme, že s riešením problematiky sa otvára vel'a d'alších významných otázok spojených s dlhodobo znevýhodnenými regiónmi. Aby sme mohli analyzovat' časové aspekty chudoby (určit' jej vývoj, dynamiku, zmeny, trvanie, atd'.), je nutné najprv definovat', na čo má časová analýza slúžit', teda, čo je jej ciel'om. Treba mat' na zreteli, že merat' možno vždy len určitý časový aspekt chu- 
doby a spôsob závisí od viacerých faktorov, predovšetkým od sledovaného ciel'a, dostupnosti zdrojov, teritoriálnej mierky, charakteru a výpovednej schopnosti vybraného konceptu, použitej metódy, možností hodnotenia a interpretácie získaných výsledkov. Každý z uvedených faktorov výrazne ovplyvňuje merania a ich výsledky, pričom hlavný dôraz treba venovat' výberu vhodného konceptu. Aj ked' je zrejmé, že každý má určité prednosti a nedostatky, je potrebné vybrat' taký koncept a spôsob merania, ktorý je jednoznačný vo vzt’ahu k ciel'u, l'ahko aplikovatel'ný a interpretovatel'ný a poskytuje relevantné poznatky o trvaní chudoby v regiónoch. $\mathrm{V}$ súčasnosti existuje niekol'ko konceptov zameraných na skúmanie dynamiky, resp. trvanie chudoby v čase (Hulme a Shepherd 2003). Medzi najviac používané patrí analýza periód (spells approach) a analýza komponentov (component approach). My sme pre náš výskum využili obidva koncepty, pomocou ktorých sme vykonali časovú typológiu okresov chudoby na Slovensku.

\section{ČASOVÁ ANALÝZA A TYPIZÁCIA OKRESOV CHUDOBY NA SLOVENSKU}

Získané poznatky a výsledky z výskumov chudoby na regionálnej i lokálnej úrovni na Slovensku poukazujú na významný časový rozmer prevalencie určitého typu chudoby v okresoch a lokalitách. Je všeobecne známe, že nepomerne väčší podiel dlhodobo chudobných žije $\mathrm{v}$ periférnych a znevýhodnených oblastiach a okresoch Slovenska. Pri časovej typizácii sa zameriame na okresy chudoby (16), ktoré boli vyčlenené na základe precíznej priestorovej analýzy za pomoci konceptu mnohonásobnej deprivácie prezentovaného v práci Michálek a Veselovská (2016) ${ }^{3}$. Pri stanovení ich ,rokov v chudobe“ budeme vychádzat' z troch relevantných atribútov (komponentov) chudoby, a to miery dlhodobej nezamestnanosti, priemernej $\operatorname{mzdy}^{4}$ a podielu osôb v hmotnej núdzi v okresoch. Pozíciu jednotlivých okresov chudoby $\mathrm{z}$ aspektu uvedených atribútov (ich priemerných hodnôt za obdobie rokov 2004 - 2016) možno sledovat' na obr. 4.

Dížku chudoby budeme analyzovat' za 13-ročné obdobie, konkrétne za roky $2004-2016^{5}$. Pozornost' zameriame na zaradenie okresov chudoby do vyčlenených typov podl'a zvolených kritérií. Časová typizácia okresov chudoby analýzou periód z aspektu kumulovanej deprivácie je zameraná na sledovanie počtu rokov, v ktorých bol okres deprivovaný minimálne v dvoch deprivačných položkách. Toto základné kritérium typizácie okresov chudoby sme z dôvodu sprehl'adnenia typizácie pracovne označili ako ,významnú“ depriváciu. Za každú deprivačnú položku sme vybrali $20 \%$ okresov s hodnotou rovnakou alebo menšou ako hodnota dolného kvintilu Q1 ${ }^{(4)}$ (mzda), respektíve $20 \%$ okresov s hodnotou rovnakou alebo väčšou ako hodnota horného kvintilu Q4 ${ }^{(4)}$ (miera dlhodobej nezamestnanosti a podiel osôb v hmotnej núdzi), teda v závislosti od charakteru deprivačnej položky.

\footnotetext{
${ }^{3}$ Uvedení autori pri identifikovaní okresov chudoby a ich typov použili metódu mnohonásobnej deprivácie. Analyzovali šest' relevantných indikátorov, ktoré vybrali na základe ich silnej korelácie s chudobou. Pri analýze boli použité dáta z Regionálnej databázy Štatistického úradu SR a Ústredia práce, sociálnych vecí a rodiny za rok 2001 a 2011 (viac vid’. citovaná práca).

${ }^{4}$ Tento atribút sme zvolili z dôvodu nedostupnosti dát o príjme za sledované priestorové jednotky - okresy, aj ked' sme si vedomí, že príjmy sú vhodnejšie a častejšie použivané pri podobných výskumoch. Avšak mzdy sledované v kombinácii s d’alším dvomi sledovaným atribútmi sa vzájomne dopíñajú a tvoria relevantnú skupinu indikátorov sledovania temporality chudoby. Ich vzájomná komplementarita zachytáva takmer celú populáciu chudobného obyvatel'stva.

${ }^{5} \mathrm{~V}$ tab. 1 sú zachytené hodnoty sledovaných atribútov v párnych rokoch sledovaného obdobia.
} 
Na základe uvedených analýz sme vykonali typizáciu okresov chudoby z aspektu ich deprivácie podl'a sledovaných atribútov. Následne sme sledovali, v ktorých rokoch okres vykazoval chudobu. Týmto spôsobom sme okresy chudoby začlenili do štyroch typov, ktoré určujú profil okresov chudoby na časovej osi.

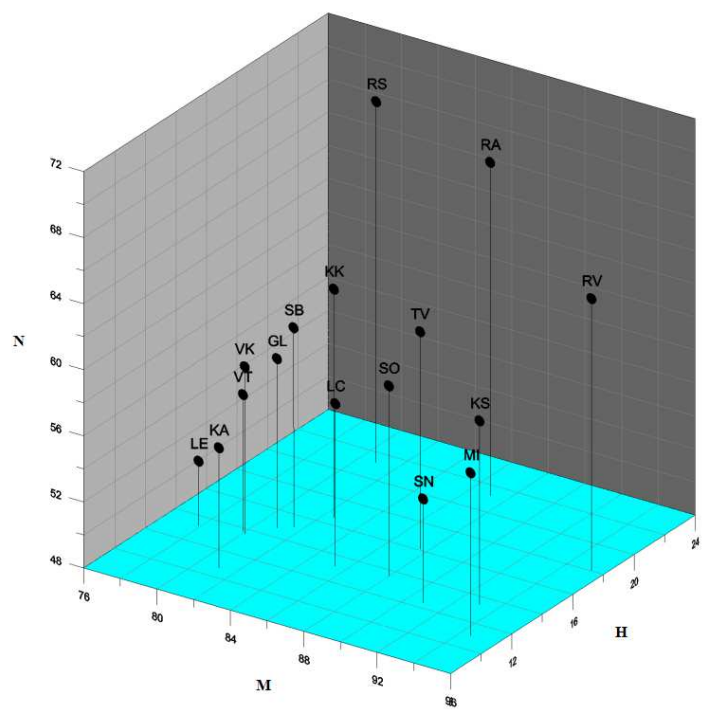

Obr. 4. Pozícia chudobných okresov z aspektu vybraných atribútov Zdroj: ŠÚ SR (2005 - 2017) a ÚPSVaR (2005 - 2017)

Tab. 1. Úroveň deprivácie v sledovaných rokoch v okresoch chudoby na Slovensku

\begin{tabular}{lccccccc}
\hline Okres & 2004 & 2006 & 2008 & 2010 & 2012 & 2014 & 2016 \\
\hline Levoča & $\mathrm{M}$ & $\mathrm{M}+\mathrm{H}$ & $\mathrm{N}+\mathrm{H}$ & $\mathrm{H}$ & $\mathrm{H}$ & & \\
Krupina & & & $\mathrm{N}$ & $\mathrm{M}$ & $\mathrm{M}+\mathrm{N}$ & $\mathrm{M}$ & $\mathrm{M}$ \\
Lučenec & $\mathrm{N}+\mathrm{H}$ & $\mathrm{H}$ & $\mathrm{N}+\mathrm{H}$ & $\mathrm{M}+\mathrm{N}+\mathrm{H}$ & $\mathrm{N}+\mathrm{H}$ & $\mathrm{H}$ & $\mathrm{H}$ \\
Vel'ký Krtíš & $\mathrm{N}+\mathrm{H}$ & $\mathrm{M}+\mathrm{N}+\mathrm{H}$ & $\mathrm{M}+\mathrm{N}+\mathrm{H}$ & & & $\mathrm{M}$ & $\mathrm{M}$ \\
Trebišov & $\mathrm{N}+\mathrm{H}$ & $\mathrm{N}+\mathrm{H}$ & $\mathrm{H}$ & $\mathrm{N}+\mathrm{H}$ & $\mathrm{N}+\mathrm{H}$ & $\mathrm{N}+\mathrm{H}$ & $\mathrm{H}$ \\
Rimavská Sobota & $\mathrm{N}+\mathrm{H}$ & $\mathrm{N}+\mathrm{H}$ & $\mathrm{N}+\mathrm{H}$ & $\mathrm{M}+\mathrm{N}+\mathrm{H}$ & $\mathrm{M}+\mathrm{N}+\mathrm{H}$ & $\mathrm{M}+\mathrm{N}+\mathrm{H}$ & $\mathrm{M}+\mathrm{N}+\mathrm{H}$ \\
Spišská Nová Ves & $\mathrm{H}$ & $\mathrm{N}+\mathrm{H}$ & $\mathrm{H}$ & $\mathrm{H}$ & & $\mathrm{H}$ & \\
Rožňava & $\mathrm{N}+\mathrm{H}$ & $\mathrm{N}+\mathrm{H}$ & $\mathrm{N}+\mathrm{H}$ & $\mathrm{N}+\mathrm{H}$ & $\mathrm{N}+\mathrm{H}$ & $\mathrm{N}+\mathrm{H}$ & $\mathrm{N}+\mathrm{H}$ \\
Košice-okolie & $\mathrm{N}+\mathrm{H}$ & $\mathrm{N}+\mathrm{H}$ & $\mathrm{N}+\mathrm{H}$ & $\mathrm{H}$ & $\mathrm{H}$ & $\mathrm{N}+\mathrm{H}$ & $\mathrm{H}$ \\
Revúca & $\mathrm{N}+\mathrm{H}$ & $\mathrm{N}+\mathrm{H}$ & $\mathrm{N}+\mathrm{H}$ & $\mathrm{N}+\mathrm{H}$ & $\mathrm{N}+\mathrm{H}$ & $\mathrm{N}+\mathrm{H}$ & $\mathrm{N}+\mathrm{H}$ \\
Vranov nad Topl'ou & $\mathrm{M}+\mathrm{H}$ & $\mathrm{M}+\mathrm{H}$ & $\mathrm{M}+\mathrm{H}$ & $\mathrm{M}+\mathrm{N}+\mathrm{H}$ & $\mathrm{M}+\mathrm{N}+\mathrm{H}$ & $\mathrm{M}+\mathrm{N}+\mathrm{H}$ & $\mathrm{M}+\mathrm{N}+\mathrm{H}$ \\
Sabinov & $\mathrm{M}+\mathrm{N}+\mathrm{H}$ & $\mathrm{M}+\mathrm{N}+\mathrm{H}$ & $\mathrm{M}+\mathrm{N}+\mathrm{H}$ & $\mathrm{N}+\mathrm{H}$ & $\mathrm{N}+\mathrm{H}$ & $\mathrm{N}+\mathrm{H}$ & $\mathrm{N}+\mathrm{H}$ \\
Gelnica & $\mathrm{H}$ & $\mathrm{N}+\mathrm{H}$ & $\mathrm{M}+\mathrm{N}+\mathrm{H}$ & $\mathrm{M}+\mathrm{N}+\mathrm{H}$ & $\mathrm{M}+\mathrm{H}$ & $\mathrm{M}+\mathrm{N}+\mathrm{H}$ & $\mathrm{N}+\mathrm{H}$ \\
Kežmarok & $\mathrm{N}+\mathrm{H}$ & $\mathrm{N}+\mathrm{H}$ & $\mathrm{N}+\mathrm{H}$ & $\mathrm{M}+\mathrm{N}+\mathrm{H}$ & $\mathrm{M}+\mathrm{N}+\mathrm{H}$ & $\mathrm{M}+\mathrm{N}+\mathrm{H}$ & $\mathrm{M}+\mathrm{N}+\mathrm{H}$ \\
Michalovce & $\mathrm{N}+\mathrm{H}$ & & $\mathrm{N}$ & & $\mathrm{N}$ & $\mathrm{N}$ & $\mathrm{N}+\mathrm{H}$ \\
Sobrance & $\mathrm{M}+\mathrm{N}+\mathrm{H}$ & $\mathrm{N}+\mathrm{H}$ & $\mathrm{N}+\mathrm{H}$ & $\mathrm{N}+\mathrm{H}$ & $\mathrm{N}+\mathrm{H}$ & $\mathrm{N}+\mathrm{H}$ & $\mathrm{N}+\mathrm{H}$ \\
\hline
\end{tabular}

$\mathrm{M}$ - priemerná mzda, $\mathrm{N}$ - dlhodobá nezamestnanost', $\mathrm{H}$ - hmotná núdza

Pozn.: Tmavšie (šedé) pozadie označuje roky, ked' bol okres deprivovaný z aspektu všetkých troch sledovaných atribútov.

Zdroj: ŠÚ SR (2005 - 2017) a ÚPSVaR (2005 - 2017). 
Hodnoty $\mathrm{v}$ analyzovaných okresoch chudoby sa pohybovali $\mathrm{v}$ intervale od 1 do 7, pričom čísla $\mathrm{z}$ tohto intervalu vyjadrujú počet rokov v chudobe. Jednotlivé časové typy chudoby môžeme sledovat' na mape (obr. 5).

Typ 1 - Okresy chronickej (permanentnej) chudoby (chronic alebo permanent poverty) predstavujú najviac rozšírený typ, pričom takýchto okresov chudoby je na Slovensku celkovo sedem. Ich spoločným znakom je významná deprivácia vo všetkých siedmich sledovaných rokoch. Najhoršia je situácia v okresoch Kežmarok, Vranov nad Topl'ou a Rimavská Sobota, ktoré okrem zachytenej chudoby vo všetkých rokoch charakterizuje aj nepriaznivý trend, čo znamená, že v posledných troch sledovaných rokoch vykazujú nárast deprivačných položiek. Uvedené okresy možno právom považovat' za chronické okresy chudoby s vysokou depriváciou. O niečo lepšie sú na tom okresy Sabinov a Sobrance, ktoré naopak v sledovaných rokoch zaznamenali pokles výskytu deprivačných položiek. Okresy Revúca a Rožňava počas celého obdobia vykazovali chudobu v dvoch deprivačných položkách, čo v rámci tohto typu okresov chudoby indikuje ich stabilnú a zároveň strednú úroveň deprivácie.

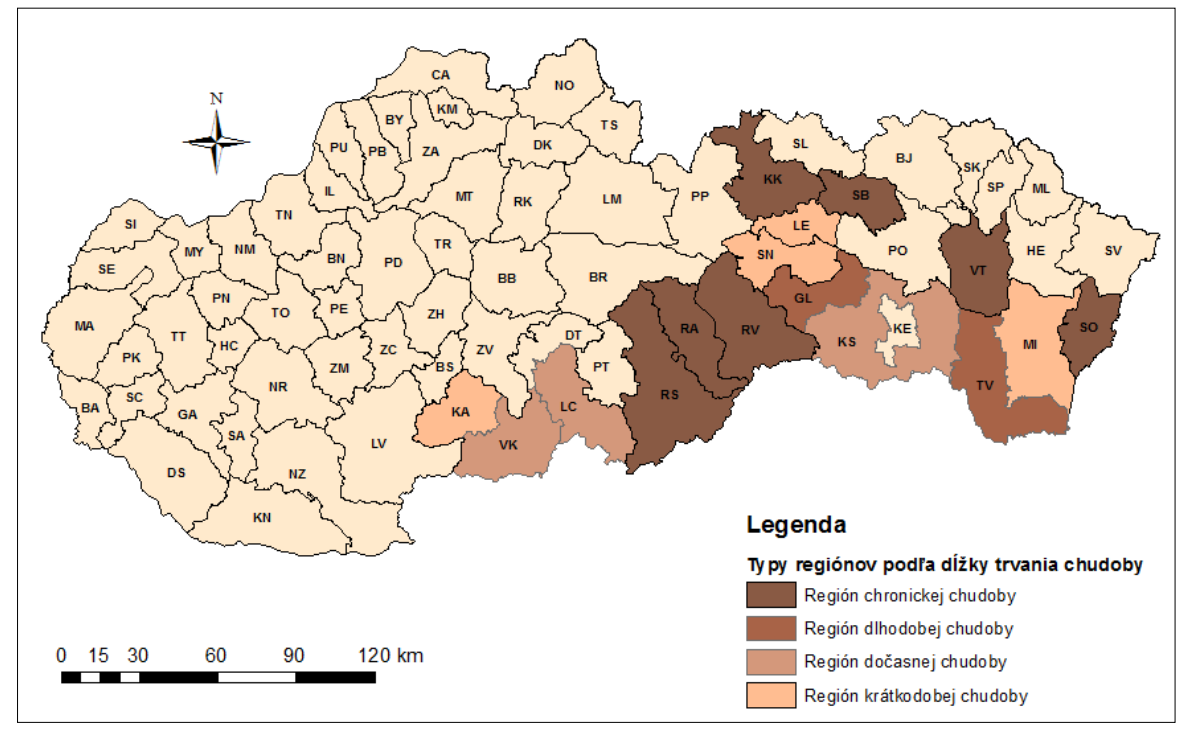

Obr. 5. Typy okresov z aspektu dížky trvania chudoby

Typ 2 - Okresy dlhodobej chudoby (long-term poverty) predstavujú okresy, $\mathrm{v}$ ktorých bola zaznamenaná významná deprivácia $\mathrm{v}$ piatich sledovaných rokoch. Celkovo do tohto typu patria dva okresy chudoby, a to okresy Gelnica a Trebišov. $\mathrm{V}$ rámci tohto typu je horšia situácia v okrese Gelnica, ktorý až v troch rokoch vykazoval depriváciu vo všetkých troch položkách a v d'alších troch rokoch v dvoch položkách. Okres Trebišov zaznamenal v piatich rokoch depriváciu „len“ v dvoch položkách.

Typ 3 - Okresy dočasnej (prechodnej) chudoby (temporary poverty), v ktorých deprivácia bola zachytená v troch (okres Vel'ký Krtíš) alebo štyroch sledovaných rokoch (okresy Lučenec a Košice-okolie). Kým okres Vel'ký Krtíš sa vyznačuje vysokou depriváciou v dvoch rokoch, okres Lučenec len v jednom roku, okres Ko- 
šice-okolie ju nevykazuje ani v jednom roku. Naopak, z aspektu vývoja môžeme zlepšenie (pokial' ide o vývoj sledovaných deprivácií) sledovat' práve v okrese Vel'ký Krtíšs.

Typ 4 - Okresy krátkodobej chudoby (short-term poverty). Tento typ je charakterizovaný nízkou depriváciou okresu, aj to len v jednom, maximálne dvoch sledovaných rokoch. Do tohto typu patria štyri okresy chudoby, a to okresy Levoča, Krupina, Spišská Nová Ves a Michalovce. V rámci tohto typu je najhoršia situácia v okrese Levoča, ktorý vykazoval depriváciu v dvoch rokoch. Z aspektu vývoja horšie vyznieva situácia pre okres Krupina vykazujúci depriváciu k roku 2012, okres Spišská Nová Ves k roku 2006 a okres Michalovce k roku 2004.

\section{VZŤAH MEDZI ZÁVAŽNOSŤOU A DĹŽKOU CHUDOBY NA SLOVENSKU}

Vzt'ah medzi sledovanými fenoménmi je možné, a v mnohých prípadoch výhodné, skúmat' pomocou regionálnych dát. Ich využitím môžeme získat' širšiu poznatkovú bázu, pomocou ktorej sa dá dokázat' platnost' alebo neplatnost' hypotézy potvrdzujúcej alebo zamietajúcej sledovaný vzt'ah a vykonat' jeho detailnejšiu evaluácia a exaktnejšiu explanáciu. Vykonaná korelačná analýza a dosiahnuté hodnoty Spearmanovho korelačného koeficientu (d’alej Skk) medzi sledovanými javmi nám ukázali silnú koreláciu (hodnota Skk 0,8102). Ako vidíme na obr. 6, meranými bodmi možno preložit' priamku, ktorá má rastúci charakter. Priebeh priamky indikuje, že medzi sledovanými javmi ide o priamu lineárnu závislost'. Zistená vysoká korelácia medzi sledovanými fenoménmi ukazuje, že t’aživost' sociálnej situácie priamoúmerne rastie s dížkou chudoby. V súčasnosti absentujú, resp. len osamotene sa vyskytujú schémy, ktoré by dokázali vystihnút' a v plnej miere interpretovat' získané poznatky. Ako vhodné explanačné schémy sa javia schémy založené, resp. vychádzajúce zo sociálnych teórií nerovností, núdze, nedostatku a exklúzie. Obrázok 6 súčasne zachytáva pozíciu jednotlivých okresov chudoby z aspektu hodnôt závažnosti a trvania ich chudoby. Indikuje poradie okresov z aspektu sledovaných atribútov, ako aj vzájomnú pozíciu atribútov (atribútovú súvislost') v jednotlivých okresoch.

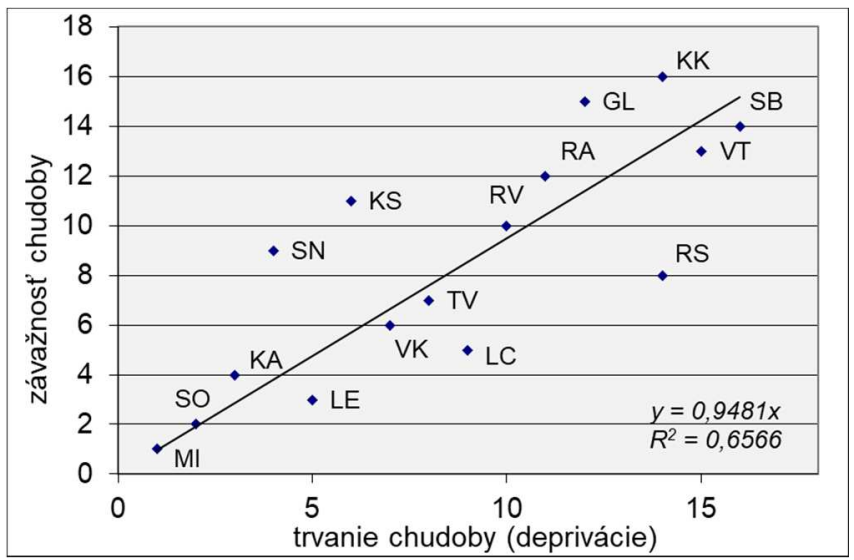

Obr. 6. Závislost' medzi trvaním a závažnost'ou chudoby v chudobných okresoch SR Zdroj: ŠÚ SR (2005 - 2017) a ÚPSVaR (2005 - 2017). 


\section{ZÁVER}

Časové aspekty chudoby patria k málo prebádaným témam, pričom absolútne absentujú nielen $\mathrm{v}$ slovenských, ale aj $\mathrm{v}$ širších stredoeurópskych geografických výskumoch. Väčšina priestorovo orientovaných vedcov, ktorí sa venujú problémom chudoby, sa prevažne zameriava na priestorovú diferenciu a koncentráciu chudoby v priestore. Takýto výskum však zostáva len v polohe sledovania úrovne chudoby vo vyčlenených priestorových jednotkách a v identifikácii chudobných oblastí, okresov, areálov alebo jadier chudoby. Napriek tomu, že výskum časových aspektov chudoby, zvlášt' výskyt chronickej chudoby v niektorých územiach, má vysokú relevanciu, je táto problematika stále na okraji záujmu. Z uvedených dôvodov vznikol aj tento príspevok, ktorý prináša detailnejší pohl'ad na výskyt pretrvávajúcej chudoby na úrovni relatívne malých priestorových jednotiek. Jeho prínos vidíme $\mathrm{v}$ troch rovinách. $\mathrm{V}$ rovine teoreticko-konceptuálnej predstavuje všeobecný teoretický rámec a významné súvislosti takýchto výskumov a súčasne poukazuje na ich spoločenský význam. Príspevok potvrdil význam štúdia predmetnej problematiky a zosystematizoval existujúce najdôležitejšie poznatky o problematike. V rovine empirickej ide o pilotný pokus, ktorého prínos spočíva $\mathrm{v}$ konkrétnej analýze a identifikácii najvýznamnejších časových aspektov chudoby v okresoch chudoby na Slovensku a ich typizácii. Na základe dížky pozorovaného obdobia (v zhode s autormi Muffels et al. 2000) možno v OCH potvrdit' zastúpenie všetkých štyroch časových typov chudoby, ktoré určujú ich profil na časovej osi. Analýza okrem iného ukázala, že vyše polovica zo sledovaných okresov chudoby (9 zo 16) sa vyznačuje chronickou (7) alebo dlhodobou chudobou (2). Súčasne ukázala, že v sledovanom období okresy chudoby vykázali určitú, značne diferencovanú dynamiku. Výrazné rozdiely medzi regiónmi boli dokázané aj z aspektu ich vývojových trendov. Uvedené skutočnosti poukazujú na heterogenitu, rozdielne predpoklady a potenciál, ktoré $\mathrm{v}$ jednotlivých okresoch znamenajú prehíbenie ich chudoby, alebo naopak skutočnost', že časom sa z nej niektoré môžu vymanit'. A konečne tretí prínos spočíva v potvrdení stanovenej hypotézy, že aj na Slovensku medzi závažnost'ou a trvaním chudoby existuje priamy vzt'ah. Ťažké formy chudoby a extrémna chudoba priamoúmerne rastú s jej trvaním a najviac postihujú chronicky chudobné okresy. Výsledky poukazujú na skutočnost', že CHCH sa vyskytuje v okresoch, pre ktoré je charakteristická kombinácia neistôt spojených najmä s nedostatočným hospodárskym rozvojom, nepriaznivým trhom práce (nedostatok pracovných miest a nevhodná štruktúra pracovných príležitosti), viacnásobným regionálnym znevýhodnením (nepriaznivá poloha, vonkajšia i vnútorná periféria, atd'.), nedostatočnou infraštruktúrou, nepriaznivými štruktúrami obyvatel'stva (napr. zvýšeným podielom prestarnutého obyvatel'stva alebo naopak detskej zložky populácie), slabým l’udským a pracovným kapitálom (z aspektu vzdelania, kvalifikácie, atd'.), sociálnou exklúziou a inými nevýhodami identifikovaných okresov. Možno konštatovat', že na Slovensku je t’aživá chudoba $\mathrm{v}$ chronicky chudobných okresoch, podobne ako aj $\mathrm{v}$ iných krajinách, spájaná $\mathrm{s}$ vel'kým počtom osôb závislých na sociálnych dávkach najmä $\mathrm{v}$ dôsledku dlhodobej nezamestnanosti, $\mathrm{s}$ rastúcim počtom zadlžených osôb a domácností, vysokým podielom viacdetných a rastom jednorodičovských rodín závislých od sociálnej pomoci, rastúcim podielom l'udí bez domova, dlhodobou koncentráciou chudobných l'udí v určitých periférnych, resp. marginálnych územiach s nulovým alebo nízkym ekonomickým rastom. Obyvatel'stvo žijúce v takýchto okresoch sa nachádza v priestorovej pasci chudoby, z ktorej je vel’mi t’ažké sa vymanit'. 
Výskumy a analýzy temporality a časopriestorových aspektov chudoby sú dôsledkom a reakciou na spoločenské výzvy a požiadavky súvisiace s tvorbou nových prístupov sociálnej a regionálnej politiky, ktorých nevyhnutnou súčast'ou sú i kompletné informácie o vývoji a trvaní chudoby v postihnutých okresoch. Na druhej strane sporadické výsledky, ktoré sú v súčasnosti k dispozícii, sú málo akceptované, nedostatočne aplikované a často manipulované. Je samozrejme potrebné nad'alej skúmat' uvedené vzt'ahy, analyzovat' dlhšie časové horizonty a rozšírit' analýzy o d'alšie dôležité (časové) charakteristiky chudoby. Zároveň je nutné získané výsledky vhodne interpretovat' $\mathrm{v}$ rámci ekonomických, geografických, sociologických a d'alších teórií. Z aspektu využitia výsledkov je potrebné identifikovat' spoločné a špecifické črty a príčiny v okresoch, ktoré podmieňujú a determinujú obdobie trvania a úroveň chudoby. Takto a podobne orientované výskumy nám môžu poskytnút' potrebné informácie a poznatky pre identifikáciu determinantov chudoby a rozšírit' možnosti pri hl'adaní príčin, podmienok a faktorov chudoby v konkrétnych regiónoch. Získané poznatky prezentované $\mathrm{v}$ príspevku, či už z oblasti teoreticko-konceptuálnej alebo konkrétne výsledky empirického výskumu na Slovensku, predstavujú určitý rámec, ktorý môže byt' aplikovaný aj v iných krajinách.

Príspevok vznikol v rámci riešenia vedeckého projektu č. 2/0009/18 financovaného grantovou agentúrou VEGA.

\section{LITERATÚRA}

BARRETT, C. B., CARTER, M. R. (2013). The economics of poverty traps and persistent poverty: empirical and policy implications. The Journal of Development Studies, 49, 976-990.

BIRD, K., HIGGINS, K., HARRIS, D. (2010). Spatial poverty traps. Working Paper 321 and CPRC Working Paper 161. London (Overseas Development Institute - ODI) and Chronic Poverty Research Centre - CPRC).

CARTER, M. R., BARRETT, C. B. (2006). The economics of poverty traps and persistent poverty: an asset-based approach. The Journal of Development Studies, 42, 178-199.

CHRONIC POVERTY RESEARCH CENTRE (2004). Chronic poverty report 2004-05. CPRC Working Paper 13. Manchester (CPRC, University of Manchester).

CHRONIC POVERTY ADVISORY NETWORK - CPAN (2014). Chronic poverty report 2014-15. London (Overseas Development Institute).

DORLING, D., PRITCHARD, J. (2010). The geography of poverty, inequality and wealth in the UK and abroad: because enough is never enough. Applied Spatial Analysis and Policy, 3, 1-106.

GORDON, D., ADELMAN, L., ASHWORTH, K., BRADSHAW, J., LEVITAS, R., MIDDLETON, S. (2000). Poverty and social exclusion in Britain. York (Joseph Rowntree Foundation).

HULME, D., MOORE, K., SHEPHERD, A. (2001). Chronic poverty: meanings and analytical frameworks. CPRC Working Paper 2. Manchester (Institute of Development Policy and Management - IDPM, University of Manchester).

HULME, D., SHEPHERD, A. (2003). Conceptualising chronic poverty. World Development, 31, 403-423.

HULME, D., McKAY, A. (2005). Identifying and understanding chronic poverty: beyond monetary measures. Working paper 30. Manchester (Chronic Poverty Research Centre - CPRC, University of Manchester, University of Bath).

JALAN, J., RAVALLION, M. (2000). Is transient poverty different? Evidence for rural China. The Journal of Development Studies, 36(6), 82-99.

JENKINS, S, P. (2011). Changing fortunes: income mobility and poverty dynamics in Britain. Oxford (Oxford University Press). 
MICHÁLEK, A., VESELOVSKÁ, Z. (2016). Identifikácia okresov chudoby na Slovensku, ich vývoj a zmeny v rokoch 2001 - 2011. In Michálek, A., Podolák, P., eds. Regióny chudoby na Slovensku. Bratislava (Geografický ústav SAV), pp. 31-49.

MUFFELS, R., FOUARGE, D., DEKKER, R. (2000). Longitudinal poverty and income inequality: a comparative panel study for the Netherlands, Germany and the UK. MPRA Paper No. 13298. OSA Institute for Labour Studies.

SHEPHERD, A., SCOTT, L. (2011). Tackling chronic poverty: the policy implications of research on chronic poverty and poverty dynamics. Chronic Poverty Research Centre (CPRC). Manchester (The University of Manchester).

ŠTATISTICKÝ ÚRAD SLOVENSKEJ REPUBLIKY (2005 - 2017). RegDat, [Online]. Dostupné na: www.statistics.sk [cit: 2017-03-23].

UK DEPARTMENT FOR INTERNATIONAL DEVELOPMENT (2013). Regional dimension of poverty and vulnerability in Nepal. Summary Report. Discussion Paper (UK DFID), [Online]. Dostupné na: https://www.gov.uk/government/uploads/system/ uploads/attachment_data/file/204015/Regional-Dimensions-PovertyNepal.pdf [cit: 2014 -12-07].

ÚPSVaR (2005-2017). Nezamestnanost': štvrt'ročné štatistiky, [Online]. Dostupné na: http://www.upsvar.sk/statistiky/nezamestnanost-stvrtrocne-statistiky/ [cit: 2017-04-03].

Anton Michál ek

\section{TEMPORALITY OF POVERTY IN SELECTED DISTRICTS OF SLOVAKIA}

This article focuses on conceptual-methodological and empirical aspects of the study of poverty temporality in pre-identified spatial units - the districts of poverty. In addition to the theoretical and methodological objectives, it focuses on monitoring the duration of poverty in poverty districts, identifying their types, identifying chronically poor districts, and examining the relationship between the severity of poverty and its duration in Slovakia. To achieve the above objectives, methods of period analysis, component analysis and Spearman correlation coefficient were used.

The results of the analysis revealed the differentiated character of the identified poverty districts from the aspect of its duration. Based on their time classification and categorization, a high representation of districts of chronic poverty can be noted. From the 16 poverty districts, more than half include chronically poor districts, all of which are characterized by three key features of permanent poverty - persistence (long duration), multidimensionality and severity. The results also confirmed the hypothesis of a significant correlation between the severity of poverty (depth) and the chronicity of poverty (persistence). The high correlation between these observed phenomena has shown that social tensions are growing steadily with the persistence of the poverty.

The main contribution of this article is to provide a general conceptual guide and one of the solutions on how to analyze the most significant time characteristics of poverty and their relationship to the level of poverty in selected spatial units. The presented concepts and methodical procedures for the identification of chronically poor districts, the complex time typology of poverty regions and the determination of the degree of dependence between the duration and the level of poverty, can be used and applied in countries with a comparable socio-economic situation and development of Central and Eastern Europe. 
